IZA DP No. 5071

Black-White Gap in Self-Employment in the U.S.: Do Cohort and Within Race Differences Exist?

Ruth Uwaifo Oyelere

Willie Belton

July 2010 


\title{
Black-White Gap in Self-Employment in the U.S.: Do Cohort and Within Race Differences Exist?
}

\author{
Ruth Uwaifo Oyelere \\ Georgia Institute of Technology \\ and IZA \\ Willie Belton \\ Georgia Institute of Technology
}
Discussion Paper No. 5071
July 2010

IZA

P.O. Box 7240

53072 Bonn

Germany

Phone: +49-228-3894-0

Fax: +49-228-3894-180

E-mail: iza@iza.org

Any opinions expressed here are those of the author(s) and not those of IZA. Research published in this series may include views on policy, but the institute itself takes no institutional policy positions.

The Institute for the Study of Labor (IZA) in Bonn is a local and virtual international research center and a place of communication between science, politics and business. IZA is an independent nonprofit organization supported by Deutsche Post Foundation. The center is associated with the University of Bonn and offers a stimulating research environment through its international network, workshops and conferences, data service, project support, research visits and doctoral program. IZA engages in (i) original and internationally competitive research in all fields of labor economics, (ii) development of policy concepts, and (iii) dissemination of research results and concepts to the interested public.

IZA Discussion Papers often represent preliminary work and are circulated to encourage discussion. Citation of such a paper should account for its provisional character. A revised version may be available directly from the author. 
IZA Discussion Paper No. 5071

July 2010

\section{ABSTRACT}

\section{Black-White Gap in Self-Employment in the U.S.: Do Cohort and Within Race Differences Exist?}

In this paper we ask three questions: First, is there evidence of a Black-White gap in selfemployment between 1994-2002 and could the inclusion of the White immigrant population be driving this result? Second, do within race differences in self-employment exist among the U.S. born? Finally, do cohort differences in the Black-White self-employment gap exist among the U.S. born? These questions are based on some of the regression findings in our earlier paper focused on the role of information and institutions in understanding the BlackWhite gap in self-employment. We find that the Black-White self-employment gap is not driven by the existence of White immigrants in the data set. In addition, we find that within race and cohort differences exist in the Black-White self-employment gap. A subgroup of U.S. born African-Americans have a self-employment probability that is identical to that of U.S. born White-Americans. In addition, younger cohorts of African-Americans have a much smaller self-employment gap than do older African-Americans.

JEL Classification: J10, J11, J15, L26

Keywords: $\quad$ self-employment, disparities, black-white gap

Corresponding author:

Ruth Uwaifo Oyelere

Georgia Institute of Technology

School of Economics

221 Bobby Dodd Way

Atlanta, GA 30332-0615

USA

E-mail: ruth.uwaifo@econ.gatech.edu 


\section{Introduction}

It has been well documented in the literature that ethnicity matters in the determination of selfemployment rates. ${ }^{1}$ In particular, African-American self-employment rates lag far behind those of White-Americans who are three times more likely to be self-employed. The documented causes of low African-American self-employment include significant differences in demographic factors such as education, discrimination in lending, differences in financial capital, and disparities in generational transfers of human capital (i.e., having parents who were self-employed). ${ }^{2}$ However, after controlling for all these factors in a regression analysis, the gap in self-employment remains.

In this paper we explore three related questions: First, is there empirical evidence of a BlackWhite self-employment gap between 1994 to 2002 and is this gap related to the inclusion of White immigrants in the data set? Second, among U.S born Blacks and Whites, do within race differences in the Black-White self-employment gap exist? Finally, among U.S born Blacks and Whites, are there cohort differences in the size of the Black-White self-employment gap?

Using 1994-2002 data from the March Consumer Population Survey (CPS) derived from IPUMS (see King et al 2004), we estimate the probability of self-employment for various ethnic groups relative to that of White-Americans with U.S. born parents (WAUBP). Controlling for demographic factors and other explanatory variables suggested in the literature, we initially provide evidence of the well documented Black-White self-employment gap. We find that the self-employment probability of Blacks is $5.5 \%$ less than that of Whites. We then partition the sample further with respect to ethnicity and citizenship in an effort to eliminate the possibility that the Black-White gap is driven by differences in immigration status. We find that even after separating Americans from the Non-American citizen, the gap persists. In effect, we show that this gap cannot be explained by the inclusion of White immigrants with high self-employment probabilities in the sample.

Next, we partition the sample of U.S. born American-Blacks and -Whites based on the immigration status of their parents. The criteria for separating U.S. born is parental birth place whether U.S. or otherwise. Partitioning the sample, Americans with both parents foreign born, Americans with only one foreign born parent and Americans with both U.S born parents are examined separately. In addition, we also partition the sample of immigrants based on an individual's home country's economic status whether developed or developing. This process is imposed based on evidence from Uwaifo Oyelere and Belton (2009), which highlights the importance of home country economic status on the probability of self-employment in the U.S. Although we provide estimates of

\footnotetext{
${ }^{1}$ Bates (1987); Borjas and Bronars (1989); Meyer (1990); Fairlie (1999); Fairlie and Meyer (1996)

${ }^{2}$ Fairlie (1999) and Bogan and Darity (2008)
} 
the probability of self-employment for both immigrant and nonimmigrant groups, we focus mainly on comparisons among the U.S. born. The exclusion of immigrants allows our research to avoid the immigrant uniqueness argument which suggests that those who immigrate show significant or unusual drive, determination, desire for risk, and independence that is evidenced by the very act of immigration.

We find that within-race differences exist. Specifically, we find that there is no Black-White gap in self-employment when comparing both U.S. born African-Americans with foreign born parents and those with foreign born fathers, to the baseline group (WAUBP). In contrast, the Black-White gap in self-employment is found solely among African-American with U.S born parents. To address the final question, we divide the population into two cohorts based on year of birth. We re-estimate the selfemployment models for each cohort and test for cohort differences in the self-employment gap. We note significant cohort differences for African-Americans with U.S born parents (AAUBP). Though we find evidence of a Black-White self-employment gap among the younger cohort of AAUBP, the gap is much smaller than the gap for the older cohort of AAUBP. However, for other subgroups of U.S born American, we find no evidence of cohort differences.

This paper contributes to the literature in two ways: First, this research is the first to highlight the fact that the Black-White self employment gap is not characteristic of all U.S born AfricanAmericans. Second, this paper is the first to show empirically that the Black-White gap in self employment is smaller among the younger cohorts of U.S born African-Americans than the older cohort.

The remaining sections of the paper is organized as follows: The second section provides a brief review of the literature related to self-employment and race. In section 3 we highlight the data used in this analysis. Sections 4 and 5 describe in detail the econometric approach. Section 6 provides the econometric results and offers robustness checks of key results. The final section contains a discussion of inferences and conclusions.

\section{Literature Review.}

Past research on the causes of low African-American self-employment rates have fallen into five areas; demographic disparities, liquidity disparities, entry into and exit out of high versus low entry barrier industries, generational transfer of human and financial capital disparities, and cultural disparities. In examining self-employment entry decision, Fairlie (1999) finds that graduation from college relative to dropping out of high school does increase the probability of self-employment more for Whites than for Blacks. However, the small size of the education coefficient in the logit regression 
indicates that education has a weak relationship with the self-employment entry decision. Looking across time, Fairlie and Meyer (2000), using the Smith and Welch (1989) decomposition method, examines the influence of demographic factors on racial trends in self-employment. They calculate the separate contribution of age, family, education, and region. They find that the Great Black migration, racial convergence in education levels, family background, and regional locations did not explain the constancy of the racial gap in self-employment during the 1960 to 1990 time frame.

Bates (1987) shows that racial difference in financial capital has a significant impact on the racial patterns of business failure. In complementary research examining self-employment entry rates, Blau and Graham (1990) and Fairlie (1999) demonstrate that racial differences in financial asset levels provide an important contribution to the Black-White gap in self-employment entry rates. More recently, Blanchflower, Levine and Zimmerman (2003) show that lending practices by financial institutions appear to exacerbate Black-White differences in access to financial capital. They argue that in the case of start-ups, as well as existing small businesses, banks are the primary source of debt capital and this capital is more readily available to White entrepreneurs than to similarly situated Blacks. Evans and Leighton (1989) show that all else remaining equal, people with greater family assets are more likely to switch to self-employment. Blanchflower and Oswald (1998) also provide evidence of the impact of wealth-transfers on self-employment. Using British data, they find that the probability of self-employment depends positively upon whether the individual ever received an inheritance or gift.

Lofstrom and Bates (2007) criticize the self-employment literature in its use of a one size fit all econometric approach to modeling the self-employment decision. They argue that industry context heavily shapes the impact of owner resource endowments on small firm entry and exit (i.e., differences in entry barriers typify different industry subgroups). They find that Blacks are more likely to exit low-barrier lines of business than similarly situated Whites. However, among highly educated Blacks the link between exit rates and race is weak for high barrier lines of small business. Fairlie and Myer (2007) find that Black firms and White firms concentrate in different industries. Black firms tend to be under represented in construction, manufacturing, whole sale trade, agricultural services, finance, insurance, and real estate but, are more concentrated in transportation, communications, public utilities, and personal services. These industry differences are associated with worse outcomes among Black-owned firms. Generational transfer of human capital is another factor highlighted in the literature. Theoretically, one would expect a strong intergenerational link in self-employment given the transmission of informal business and/or managerial knowledge as well as the transfer of financial and real capital assets from one generation to the next. Lentz and Laband (1990) finds that $53 \%$ of a sample of self-employed proprietors from the National Federation of Independent 
Business had a self-employed parent. Fairlie and Robb (2007) finds that Black business owners are much less likely to have a self-employed family member than are White business owner. This difference however, is important in explaining disparities in Black-White self-employment rates, but is unimportant in explaining racial disparities in profits, sales, and employment between Black- and White-owned businesses.

Few papers have examined within group difference in self-employment probabilities however, Bogan and Darity (2008) examine native born relative to immigrant African-Americans. They find that immigrants tend to have higher self-employment probabilities than do citizens. In addition, Oyelere and Belton (2009), looking at immigrants from developed and developing countries, provide evidence of within race differences in self-employment. To date, we have been unable to identify research that examines within racial group differences in self-employment among only U.S. born sample participants. In addition, we find no research that examines cohort differences and the self-employment gap. In this research, we further delve into these simple but interesting questions.

\section{Description of Data.}

To address the issues above, we make use of the March Current Population Survey (CPS). The CPS is a monthly U.S. household survey conducted jointly by the U.S. Census Bureau and the Bureau of Labor Statistics. The CPS samples are multi-stage stratified observations. We extract the data from IPUMS-CPS, which is microdata that provides information about individuals and households (see Kinget al 2004 for details on this data). The IPUMS-CPS data is available for 46 years (19622007). However, we focus on data from 1994-2002 for two reasons: The nature of our decomposition requires the existence of particular variables in the data set which were, in many cases, not surveyed until 1992. For example, parent's birth place is used as a control variable in our analysis but was not available in the CPS before 1992. Similarly, post-2002 the coding for race changed significantly as the variable that captures race was broken down into several subcategories making it more difficult to identify groups of interest. Specifically, prior to 2003, the number of race categories ranged from 3 (White, Negro, and other) to 5 (white, black, American Indian/Eskimo/Aleut, Asian or Pacific Islander, and other). The three category breakdown of race was thought to be too simplistic and was abandoned in 1988 for the more empirically useful five category breakdown. Beginning in 2003, respondents could report more than one race, and the number of codes rose to 21 making it more difficult to compare data with respect to race prior to 2003 with data post-2003. Individuals who classified themselves as Black previously could now identify themselves as biracial and similarly others who identified themselves as White prior to this change could also claim multiracial. One 
of the advantages of using the CPS via IPUMS is that it makes comparisons using the March CPS data more feasible as variables in IPUMS-CPS are coded identically or "harmonized" for 1962 to 2007.

Table (1) is a summary of the data used broken down by race and citizenship. Also highlighted in Table (1) are the estimated probabilities of self-employment for each category. These simple descriptive statistics without any controls seems to suggest a gap in self-employment across race and within race. The probability of self-employment is highest for naturalized White from developed countries, next is White foreigner from developed countries whereas U.S. born Blacks have the lowest self-employment probability. These simple summary statistics suggest that being an immigrant and White appears important in explaining variation in self-employment probabilities. In addition, these summary statistics suggests that inter racial differences exist in self-employment. In effect, Table (1), suggests within and between race gaps in self-employment. However, given that Table (1) only provides summary statistics, and the noted gap/disparities could be driven by observable demographic factors, it is necessary to search for these differences controlling for factors that could lead to differences in self-employment. In the following section these possibilities are explored further in a regression setting.

Table 1: Breakdown of Data by Race/Native subgroups.

\begin{tabular}{cccc}
\hline \hline & & & \\
Variable & Observations & $\%$ & Probability of Self Employment \\
\hline Black U.S. born & 127,617 & 9.77 & 0.043 \\
White U.S. born & 998,205 & 76.40 & 0.119 \\
Black Naturalized & 3,374 & 0.26 & 0.068 \\
White Naturalized LDC & 22936 & 1.76 & 0.115 \\
White Naturalized DC & 8491 & 0.64 & 0.198 \\
Black Foreign & 6,163 & 0.47 & 0.051 \\
White Foreign LDC & 61,327 & 4.69 & 0.063 \\
White Foreign DC & 7,059 & 0.54 & 0.148 \\
American Indian/Aleut/Eskimo & 18,368 & 1.41 & 0.073 \\
Asian or Pacific Islander & 47,487 & 3.63 & 0.105 \\
Other (single) race & 5,579 & 0.43 & 0.057 \\
\hline \hline
\end{tabular}

Note: We classify countries as developed and developing following the World Banks classification. LDC- Less developed country

DC-Developed country 


\section{Empirical Strategy and Results.}

\subsection{General Econometric Model.}

Recall that we are focused on three simple questions.

- Is there evidence for a Black-White gap in self-employment between 1994-2002 and could the White immigrant population be driving this result?

- Second, do significant within race differences exist among the U.S born self-employed?

- Third, do time differences in the racial self-employment gap exist among the U.S born?

To examine these issues, we estimate a simple self-employment probability model as equation (1). $\mathrm{X}$ is a matrix of all the possible factors impacting the probability of self-employment. If $\mathrm{Y}=1$, an individual is self-employed, whereas $\mathrm{Y}=0$ indicates that an individual is a wage-earner. For the purpose of estimation, we rewrite this function as shown in equations (2), (3) and (4) and employ probit, logit, and linear modeling strategies. We initially estimate a parsimonious form of equations (2)-(4) with minimal controls to address our first question. We then extend the model using additional control variables including race related dummy variables that informs our second question as well as provide robustness check on the results. To address the third question, we re-estimate the equations above separately for those born before 1970 and those born post 1970 .

$$
\begin{gathered}
\operatorname{Prob}(Y=1)=F\left(\beta^{\prime} X\right) \\
Y=\theta_{0}+\theta_{1} \Omega+\theta_{2} Z+\theta_{3} W+\sum_{i} \mu_{i} R_{i}+\epsilon \\
\operatorname{Prob}(Y=1)=\Phi\left(\alpha_{0}+\alpha_{1} \Omega+\alpha_{2} Z+\alpha_{3} W+\sum_{i} \psi_{i} R_{i}+\epsilon\right) \\
\operatorname{Prob}(Y=1)=\Lambda\left(\delta_{0}+\delta_{1} \Omega+\delta_{2} Z+\delta_{3} W+\sum_{i} \chi_{i} R_{i}+\epsilon\right)
\end{gathered}
$$

As in equation (1), the dependent variable in equations (2), (3), and (4) is a binary indicator which takes on a value of 1 if an individual is self-employed and a value of 0 if the individual is a wageearner. $\Phi($.$) in equation (3) indicates the standard normal distribution. We estimate and present$ both the coefficients and the marginal effects of each variable from this estimation. The marginal effects represent the impact of an infinitesimal change in each independent continuous variable on 
the probability of self-employment, providing the most straight forward interpretation of estimated results from the probit models. ${ }^{3} \Lambda($.$) in equation (4) indicates the logistic cumulative distribution$ function. For ease of interpretations of our logit model estimates, we focus on the odds ratio. The odds ratio is the exponentiated coefficients in an ordinary logistic regression. Our estimated coefficients from the linear probability specifications of the binary regression model in equation (2) also have straight-forward interpretations. However, we do not focus on these estimates because estimated coefficients using linear probability models can take on a value outside the unit interval if appropriate restrictions are not imposed.

Variables included in the $\Omega$ matrix are demographic variables that could potentially impact the probability of choosing self-employment including sex, education, number of children in the family, size of the family, and marital status. $Z$ is a matrix of dummy variables including year dummies, region, and state fixed effects. The vector $W$ captures the proxy for wealth. Bearse (1984) argues that ownership of financial assets is positively correlated with the probability of entrepreneurship, therefore, a measure of wealth must be included in self-employment models. In this paper, we make use of two proxies for wealth; interest income and dividend income. We cannot control for wealth using standard wealth measures as these variables are not available in the CPS. As defined in the CPS, interest income captures how much pre-tax income (if any) the respondent received from interest on saving accounts, certificates of deposit, money market funds, bonds, treasury notes, IRAs, and/or other investments which paid interest. In contrast, dividend income captures what respondents received from stocks and mutual funds during the previous calendar year. Interest income provides a broader proxy of wealth, however, using dividend income as a wealth proxy allows examination of the robustness of our results.

To provide evidence for the validity of our wealth proxies, we turn to the Survey of Consumer Finance (SCF). We cannot use the SCF dataset for our regression analysis despite its rich information on wealth because it does not included necessary questions that will allow examination of our second and third questions of interest. However, we can use this dataset to provide evidence in support of our two proxies. Using the SCF, we calculate the correlation coefficients between different measures of wealth in the SCF and both dividend income and interest income. We find that both proxies have correlation coefficients exceeding (0.5), which implies that both measures are reasonable proxies for wealth. We estimate models using both wealth proxies and get similar results, however, we focus primarily on results obtained using interest income. We also estimate models using both proxies simultaneously, however, this adjustment does not change the results significantly. Moreover, we

\footnotetext{
${ }^{3}$ For race dummy variables, the interpretations of marginal effects are slightly different. Estimates capture the change in the probability of self-employment for a particular racial group relative to the baseline group.
} 
focus on the interest income proxy because fewer people report dividend income reducing the sample size by almost $50 \%$. Using the small sample of those with dividend income could lead to serious selectivity issues reducing the possibility of generalizing our results. ${ }^{4}$ The $\mathrm{R}$ matrix contains race related variables and our unique race decomposition strategy which allows estimation of vectors of coefficients $\psi, \chi$ and $\mu$. Unless explicitly stated otherwise, the baseline comparison group for the racial dummy variables is U.S. born White-Americans. Finally, $\epsilon$ is a vector of error terms.

\subsection{Results for Question 1: Confirming the Evidence of a Black-White En- trepreneurship Gap.}

Table (2) provides the results we use to address the first question of interest. We make use of probit, logit, and linear probability models to ensure the robustness of our results. Using the pre-2002 standard approach, we partition the data by race into five categories; White, Black, Asian/Pacific Islander, American Indian/Eskimo/Aleut and Other. Table (2) is also partitioned by wealth indicators; columns (1) -(4) use interest income as the wealth proxy and columns (5) - (8) use dividend income as the wealth proxy. Table (2) provides evidence that our results are generally consistent with the self-employment literature. There is evidence of a Black-White self-employment gap in 1994-2002 data. The marginal effects estimate of the probit model in column (4) suggests that the probability of Black self-employment is $6.1 \%$ less than that of Whites. We also find that there is no difference in the probability of self-employment for Whites and Asians. If we use the more restrictive proxy for wealth, dividend income, the Black-White gap widens. The change in the size of the gap highlights the importance of wealth proxies in adequately controlling for the impact of wealth on the likelihood of self-employment. Given that the summary statistics in Table (1) show that White immigrants have the highest self-employment probability, it is useful to investigate whether the gap in self-employment is driven by the inclusion of White immigrants in the sample. We investigate this question in the next section.

\subsection{Is the Black-White gap in self-employment driven by White immigrants?}

The results of the previous section confirm those found in the literature highlighting the Black-White self-employment gap. However, the literature suggests that immigrants pursue self-employment at a much higher rate than do Americans and in particular, have a much higher probability of selfemployment than do African-Americans. ${ }^{5}$ Bogan and Darity (2008) using census data from 1910 to

\footnotetext{
${ }^{4}$ As mentioned earlier, using interest income as the wealth proxy provides a larger data sample and encompasses more dimensions of wealth. However, we acknowledge that both proxies are imperfect measures of wealth but represent the best choices for the data set being used.

${ }^{5}$ See Bogan and Darity 2008 and Fairlie and Robb 2008.
} 
Table 2: Evidence of the Racial Self-Employment Gap.

\begin{tabular}{|c|c|c|c|c|c|c|c|c|}
\hline \multirow[t]{3}{*}{ Variable: } & \multicolumn{4}{|c|}{ Panel A: Wealth Proxy A } & \multicolumn{4}{|c|}{ Panel B: Wealth Proxy B } \\
\hline & Odds ratio & Linear & Probit & $\begin{array}{c}\text { Probit } \\
\text { Marg.Effect }\end{array}$ & Odds ratio & Linear & Probit & $\begin{array}{c}\text { Probit } \\
\text { Marg.Effect }\end{array}$ \\
\hline & (1) & $(2)$ & $(3)$ & $(4)$ & $(5)$ & $(6)$ & (7) & $(8)$ \\
\hline log saving & $\begin{array}{c}1.1^{*} \\
(0.003)\end{array}$ & $\begin{array}{c}0.01^{*} \\
(0.0003)\end{array}$ & $\begin{array}{c}0.05^{*} \\
(0.002)\end{array}$ & $\begin{array}{c}0.009^{*} \\
(0.0003)\end{array}$ & & & & \\
\hline log dividend & & & & & $\begin{array}{l}1.055^{*} \\
(0.005)\end{array}$ & $\begin{array}{l}0.007^{*} \\
(0.001)\end{array}$ & $\begin{array}{l}0.029^{*} \\
(0.003)\end{array}$ & $\begin{array}{l}0.006^{*} \\
(0.001)\end{array}$ \\
\hline Black & $\begin{array}{l}0.443^{*} \\
(0.016)\end{array}$ & $\begin{array}{c}-0.057^{*} \\
(0.001)\end{array}$ & $\begin{array}{c}-0.404^{*} \\
(0.018)\end{array}$ & $\begin{array}{c}-\mathbf{0 . 0 6 1} * \\
(0.002)\end{array}$ & $\begin{array}{l}0.431^{*} \\
(0.032)\end{array}$ & $\begin{array}{c}-0.067^{*} \\
(0.004)\end{array}$ & $\begin{array}{c}-0.423^{*} \\
(0.036)\end{array}$ & $\begin{array}{c}-0.074^{*} \\
(0.005)\end{array}$ \\
\hline $\mathrm{A} / \mathrm{A} / \mathrm{E}$ & $\begin{array}{c}0.820^{*} \\
(0.08)\end{array}$ & $\begin{array}{c}-0.017^{*} \\
(0.008)\end{array}$ & $\begin{array}{c}-0.095^{*} \\
(0.048)\end{array}$ & $\begin{array}{c}-\mathbf{0 . 0 1 7} \\
(0.008)\end{array}$ & $\begin{array}{c}0.808 \\
(0.129)\end{array}$ & $\begin{array}{l}-0.022 \\
(0.015)\end{array}$ & $\begin{array}{l}-0.11 \\
(0.084)\end{array}$ & $\begin{array}{l}-0.022 \\
(0.016)\end{array}$ \\
\hline Asian & $\begin{array}{c}0.95 \\
(0.032)\end{array}$ & $\begin{array}{l}-0.005 \\
(0.003)\end{array}$ & $\begin{array}{l}-0.025 \\
(0.018)\end{array}$ & $\begin{array}{c}\mathbf{- 0 . 0 0 5} \\
(0.003)\end{array}$ & $\begin{array}{c}0.956 \\
(0.053)\end{array}$ & $\begin{array}{l}-0.006 \\
(0.006)\end{array}$ & $\begin{array}{c}-0.024 \\
(0.03)\end{array}$ & $\begin{array}{l}-0.005 \\
(0.006)\end{array}$ \\
\hline Other & $\begin{array}{c}0.6^{*} \\
(0.088)\end{array}$ & $\begin{array}{c}-0.044^{*} \\
(0.01)\end{array}$ & $\begin{array}{c}-0.263^{*} \\
(0.074)\end{array}$ & $\begin{array}{c}-\mathbf{0 . 0 4 2} \\
(0.01)\end{array}$ & $\begin{array}{l}0.581 \\
(0.2)\end{array}$ & $\begin{array}{c}-0.051^{* *} \\
(0.026)\end{array}$ & $\begin{array}{c}-0.302^{* *} \\
(0.174)\end{array}$ & $\begin{array}{c}-0.056^{* *} \\
(0.026)\end{array}$ \\
\hline Schooling & $\begin{array}{l}1.011^{*} \\
(0.003)\end{array}$ & $\begin{array}{c}0.002^{*} \\
(0.0003)\end{array}$ & $\begin{array}{l}0.006^{*} \\
(0.001)\end{array}$ & $\begin{array}{c}0.001^{*} \\
(0.0003)\end{array}$ & $\begin{array}{l}1.04^{*} \\
(0.005)\end{array}$ & $\begin{array}{l}0.005^{*} \\
(0.001)\end{array}$ & $\begin{array}{l}0.019^{*} \\
(0.002)\end{array}$ & $\begin{array}{c}0.004^{*} \\
(0.001)\end{array}$ \\
\hline Age & $\begin{array}{l}1.033^{*} \\
(0.003)\end{array}$ & $\begin{array}{l}-0.003^{*} \\
(0.0003)\end{array}$ & $\begin{array}{l}0.014^{*} \\
(0.002)\end{array}$ & $\begin{array}{c}0.003^{*} \\
(0.0003)\end{array}$ & $\begin{array}{l}1.021^{*} \\
(0.005)\end{array}$ & $\begin{array}{l}-0.006^{*} \\
(0.0007)\end{array}$ & $\begin{array}{c}0.006^{* *} \\
(0.003)\end{array}$ & $\begin{array}{c}0.001^{* *} \\
(0.001)\end{array}$ \\
\hline Sex & $\begin{array}{l}0.621^{*} \\
(0.008)\end{array}$ & $\begin{array}{c}-0.049^{*} \\
(0.001)\end{array}$ & $\begin{array}{c}-0.253^{*} \\
(0.007)\end{array}$ & $\begin{array}{c}-0.048^{*} \\
(0.001)\end{array}$ & $\begin{array}{l}0.672^{*} \\
(0.014)\end{array}$ & $\begin{array}{c}-0.048^{*} \\
(0.002)\end{array}$ & $\begin{array}{l}-0.216^{*} \\
(0.011)\end{array}$ & $\begin{array}{l}-0.047^{*} \\
(0.002)\end{array}$ \\
\hline Child & $\begin{array}{c}1.1^{*} \\
(0.007)\end{array}$ & $\begin{array}{l}0.011^{*} \\
(0.001)\end{array}$ & $\begin{array}{l}0.053^{*} \\
(0.003)\end{array}$ & $\begin{array}{c}0.01 * \\
(0.001)\end{array}$ & $\begin{array}{l}1.06^{*} \\
(0.011)\end{array}$ & $\begin{array}{l}0.008^{*} \\
(0.001)\end{array}$ & $\begin{array}{l}0.035^{*} \\
(0.006)\end{array}$ & $\begin{array}{l}0.008^{*} \\
(0.001)\end{array}$ \\
\hline Constant & & $\begin{array}{l}0.123^{*} \\
(0.007)\end{array}$ & $\begin{array}{l}-1.75^{*} \\
(0.04)\end{array}$ & & & $\begin{array}{l}0.141^{*} \\
(0.015)\end{array}$ & $\begin{array}{l}-1.73^{*} \\
(0.077)\end{array}$ & \\
\hline
\end{tabular}

Other Controls: Marital status, and year dummies, age squared.

A/A/E: American Indian/Aleut/Eskimo

$* 5 \%$ significance

** $10 \%$ significance 
2000 are the first to document statistically that foreigners whether White, Asian, or Black have a higher probability of self-employment than do African-Americans. They also argue that foreigners generally have more access to resources than do African-Americans. While this may be true for immigrants from developed and newly developed countries such as South Korea and Taiwan, it is difficult to make such a claim for foreign Blacks, who generally immigrated from Africa and/or the Caribbean. ${ }^{6}$ There is little evidence pointing to significant resource accessibility for these groups. In Africa and the Caribbean, levels of development and missing markets make wealth transfer and access to resources limited relative to that of countries with well developed capital markets. ${ }^{7}$ The literature provides no empirical evidence which suggest that significant numbers of wealthy Africans immigrate to the developed world. However, the brain drain literature finds that educated Africans are more likely to immigrate where markets for the sale of their educational skills are more developed. Oyelere and Belton (2009) show that home country economic status matters in the probability of self-employment for immigrants to the U.S. They find that immigrants from developing countries have lower self-employment probabilities than do both U.S. born White-Americans and immigrants from developed countries, while foreigners from developed countries have higher self-employment probabilities than do U.S born White-Americans.

Given that a significant share of White immigrants are from developed countries (whereas most Black immigrants are from developing countries), if the trends identified by Bogan and Darity (2008) and the results of Oyelere and Belton (2009) are valid, it is possible to argue that the gap in self-employment could be driven largely by the White immigrant population. To investigate this possibility, we decompose Black and White racial groups into seven subgroups defining the $\mathrm{R}$ matrix in equation (2), (3) and (4) to include foreign Blacks (FB), Foreign Whites (FW), AfricanAmericans, Whites-Americans, Asian, A/A/E,and Others. ${ }^{8}$ Using data from 1994-2002 we then re-estimate equations (2), (3) and (4) with the newly defined $\mathrm{R}$ matrix and provide results in Table (3). Using American Whites as the baseline group we focus on the marginal effects estimates summarized in columns (4) and (8). We find that even when excluding White immigrants from the base group of comparison, the gap in self-employment persists. African-American citizens are

\footnotetext{
${ }^{6}$ Yoon (1997) highlights evidence for the Korean case

${ }^{7}$ We cannot make the argument that these immigrants are well-to-do urban middle class. A large number of African immigrants come in as refugees and are typically classified as urban middle class because of educational attainment. In effect, many well educated African immigrants come to the U.S. but are generally economically poor. Given the level of poverty in many of these African countries, immigrants are more likely to have been close to or below the poverty line before immigrating. Many immigrants from Nigeria, an African country with $60 \%$ of its population below the $\$ 1$ poverty line in the 1990 s (and $75 \%$ using the $\$ 2$ poverty line), are classified as urban middle class due to their education levels.

${ }^{8}$ In this decomposition African-Americans and White Americans includes every White and Black American citizen whether U.S born or foreign born.
} 
6.1\% less likely to be self-employed than are their White American counterparts (White American citizens).

Surprisingly, we find that the probability of self-employment for foreign Whites and WhiteAmerican citizens are similar when interest income is used as a wealth proxy. However, using dividend income as a wealth proxy, results in Table (3) suggests that foreign Whites have a higher probability of self-employment than do White-Americans. This difference in results again reveals the upward selection bias in estimated coefficients when using dividend income as a proxy for wealth. Additionally, the results of Table (3) do not confirm those of Bogan and Darity (2008) with regards to foreign Blacks having a higher self-employment probability than do African-American. In fact we find that foreign Blacks and African-American have similar probability of self-employment. This could reflect recent changes in the choices to enter the ranks of the self-employed for these groups. However, the persistence of the Black-White gap even after controlling for immigration status raises the important question as to what explains this difference. ${ }^{9}$

Given that African-Americans and foreign Blacks have significantly lower self-employment probabilities than do White-Americans and White foreigners, a possible explanation for the self-employment gap could be our inability to directly control for discrimination in our estimated models. Conversely, discrimination might not explain this gap as other factors unrelated to discrimination could impact the probability of self-employment for each group. ${ }^{10}$ For example, Oyelere and Belton (2009) show that immigrants from developing countries have lower self-employment probabilities than do immigrants from developed countries. The Oyelere and Belton (2009) result could explain the low self-employment probability for foreign Blacks but does not provide an explanation for low AfricanAmerican self-employment. The similarities in self-employment probabilities for African-Americans and Foreign Blacks and for White Americans and Foreign White may suggest that within racial differences in self-employment do not exist, which is the focus of our second question. However, we investigate within race differences only among the U.S. born. This constraint is necessary as including immigrants in the analysis provides a number of challenges. Immigrants face different constraints even if they share a similar ethnic background to the U.S. born. For example, there may be language barriers. In addition, it is more difficult to find reliable wealth controls for immigrants. This is because immigrants are more likely to maintain wealth holdings abroad hence, U.S. proxies for wealth could understate wealth for immigrants. In the next section we examine empir-

\footnotetext{
${ }^{9}$ In latter sections of the paper to examine the robustness of our result, we take a "kitchen sink" approach including all variables available through the CPS that could remotely impact self-employment. We find that the estimated probability of self-employment changes somewhat with the barrage of variables, however, differences are minimal and the gap persists.

${ }^{10}$ These include language and legal barriers and the difficulty of transition into self-employment because of difference in institutions in home country in comparison to the US.
} 
ical evidence of within race differences in the probability of self-employment for U.S.born survey participants.

\section{The Black-White self-employment gap. Do within race differ- ences exist?}

To examine the issue of within race disparities in self-employment, we divide the sample of U.S born African-Americans and White-Americans into groups based on the birth place of their parents. Following Belton and Oyelere (2009), we partition Blacks born in the U.S. into four groups respectively: African-Americans with Foreign Born Parents, (AAFBP), African-Americans with U.S Born Parents (AAUBP), African-American with Foreign Born Fathers, (AAFBF) and AfricanAmericans with Foreign Born Mothers, (AAFBM). ${ }^{11}$ We initially partition U.S. born Whites into four groups, White-Americans with U.S. born parents, WAUBP, White-Americans with foreign born fathers, (WAFBF), White-Americans with Foreign Born mothers (WAFBM), and White-Americans with foreign born parent,(WAFBP). However, in an effort to make a more direct comparison between AAFBP and WAFBP, we further divide WAFBP into two groups: White-Americans with Foreign Born Parents from developed countries,(WAFBPDC) and White-Americans with Foreign Born Parents form developing countries,(WAFBPLDC). Our rational for this breakdown is recent evidence from Oyelere and Belton (2009) which finds that the economic status (whether developed or developing) of an immigrant's home country matters in the probability of being self-employed in the U.S. Since most immigrant Blacks are from developing countries there is little need to partition the AAFBP sample by home country economic status. In contrast, immigrant Whites are from both developing and developed countries, therefore, we partitioned WAFBP into those from developed countries, WAFBPDC, and those from developing countries WAFBPLDC. Given this redefinition of the WAFBP sample, it is possible to make direct comparison of AAFBP to WAFBPLDC.

\section{$5.1 \quad$ Results}

This section presents estimation results from both linear and probit models. We focus primarily on results for U.S born groups, however we present estimation result for racial subgroups. Given the large number of sub-groups, coefficients associated with all of the control variables are not explicitly presented in each tables. The results of Table (4) provide direct evidence in support of the thesis that within race differences in self employment exist. Using interest income as a wealth proxy, focusing on column (2) the marginal effects from the probit model, we find that

\footnotetext{
${ }^{11}$ Note that the group AAUBP includes those whose grandparents are foreign born.
} 
Table 3: Can White Foreigners be driving the Black-White gap in self-employment?

\begin{tabular}{|c|c|c|c|c|c|c|c|c|}
\hline Variable: & \multicolumn{4}{|c|}{$\begin{array}{l}\text { Panel A: Wealth Proxy A } \\
\end{array}$} & \multicolumn{4}{|c|}{$\begin{array}{l}\text { Panel B: Wealth Proxy B } \\
\end{array}$} \\
\hline Dep Var: Di & $\begin{array}{l}\text { dend Inc. } \\
\text { Odds ratio }\end{array}$ & Linear & Probit & $\begin{array}{c}\text { Probit } \\
\text { Marg.Effect }\end{array}$ & Odds ratio & Linear & Probit & $\begin{array}{c}\text { Probit } \\
\text { Marg.Effect }\end{array}$ \\
\hline & $(1)$ & $(2)$ & $(3)$ & $(4)$ & $(5)$ & $(6)$ & (7) & $(8)$ \\
\hline log saving & $\begin{array}{c}1.1^{*} \\
(0.003)\end{array}$ & $\begin{array}{c}0.010^{*} \\
(0.0003)\end{array}$ & $\begin{array}{c}0.05^{*} \\
(0.002)\end{array}$ & $\begin{array}{c}0.009^{*} \\
(0.0003)\end{array}$ & & & & \\
\hline log dividend & & & & & $\begin{array}{l}1.055^{*} \\
(0.005)\end{array}$ & $\begin{array}{l}0.006^{*} \\
(0.001)\end{array}$ & $\begin{array}{l}0.029^{*} \\
(0.003)\end{array}$ & $\begin{array}{l}0.007^{*} \\
(0.001)\end{array}$ \\
\hline Foreign Black & $\begin{array}{l}0.548^{*} \\
(0.081)\end{array}$ & $\begin{array}{c}-0.042^{*} \\
(0.008)\end{array}$ & $\begin{array}{c}-0.304^{*} \\
(0.072)\end{array}$ & $\begin{array}{r}-\mathbf{0 . 0 4 7} * \\
(0.009)\end{array}$ & $\begin{array}{l}0.448^{*} \\
(0.161)\end{array}$ & $\begin{array}{l}-0.057^{*} \\
(0.019)\end{array}$ & $\begin{array}{c}-0.439^{*} \\
(0.171)\end{array}$ & $\begin{array}{c}-0.074^{*} \\
(0.021)\end{array}$ \\
\hline Foreign White & $\begin{array}{l}1.056 \\
(0.04)\end{array}$ & $\begin{array}{c}0.004 \\
(0.004)\end{array}$ & $\begin{array}{c}0.027 \\
(0.020)\end{array}$ & $\begin{array}{c}\mathbf{0 . 0 0 5} \\
(0.004)\end{array}$ & $\begin{array}{l}1.24^{*} \\
(0.097)\end{array}$ & $\begin{array}{c}0.026^{*} \\
(0.01)\end{array}$ & $\begin{array}{l}0.114^{*} \\
(0.043)\end{array}$ & $\begin{array}{l}0.026^{*} \\
(0.011)\end{array}$ \\
\hline Black Citizens & $\begin{array}{l}0.439^{*} \\
(0.017)\end{array}$ & $\begin{array}{l}-0.056^{*} \\
(0.002)\end{array}$ & $\begin{array}{c}-0.408^{*} \\
(0.018)\end{array}$ & $\begin{array}{c}-\mathbf{0 . 0 6 1} \\
(0.002)\end{array}$ & $\begin{array}{c}0.433^{*} \\
(0.033)\end{array}$ & $\begin{array}{c}-0.066^{*} \\
(0.004)\end{array}$ & $\begin{array}{l}-0.42^{*} \\
(0.037)\end{array}$ & $\begin{array}{c}-0.074^{*} \\
(0.005)\end{array}$ \\
\hline $\mathrm{A} / \mathrm{A} / \mathrm{E}$ & $\begin{array}{l}0.821^{*} \\
(0.076)\end{array}$ & $\begin{array}{l}-0.017^{*} \\
(0.008)\end{array}$ & $\begin{array}{c}-0.094^{*} \\
(0.048)\end{array}$ & $\begin{array}{c}-\mathbf{0 . 0 1 7} \\
(0.008)\end{array}$ & $\begin{array}{c}0.81 \\
(0.129)\end{array}$ & $\begin{array}{l}-0.022 \\
(0.015)\end{array}$ & $\begin{array}{l}-0.10 \\
(0.084)\end{array}$ & $\begin{array}{l}-0.022 \\
(0.016)\end{array}$ \\
\hline Asian & $\begin{array}{c}0.956 \\
(0.032)\end{array}$ & $\begin{array}{l}-0.005 \\
(0.003)\end{array}$ & $\begin{array}{l}-0.025 \\
(0.018)\end{array}$ & $\begin{array}{l}-\mathbf{0 . 0 0 5} \\
(0.003)\end{array}$ & $\begin{array}{c}0.96 \\
(0.053)\end{array}$ & $\begin{array}{l}-0.005 \\
(0.006)\end{array}$ & $\begin{array}{c}-0.022 \\
(0.03)\end{array}$ & $\begin{array}{l}-0.005 \\
(0.006)\end{array}$ \\
\hline Other & $\begin{array}{l}0.602^{*} \\
(0.088)\end{array}$ & $\begin{array}{c}-0.044^{*} \\
(0.01)\end{array}$ & $\begin{array}{c}-0.262^{*} \\
(0.074)\end{array}$ & $\begin{array}{c}-\mathbf{0 . 0 4 2} \\
(0.01)\end{array}$ & $\begin{array}{c}0.583 \\
(0.2)\end{array}$ & $\begin{array}{c}-0.051^{* *} \\
(0.026)\end{array}$ & $\begin{array}{l}-0.3^{* *} \\
(0.174)\end{array}$ & $\begin{array}{c}-0.055^{* *} \\
(0.026)\end{array}$ \\
\hline Schooling & $\begin{array}{l}1.011^{*} \\
(0.003)\end{array}$ & $\begin{array}{c}0.002^{*} \\
(0.0003)\end{array}$ & $\begin{array}{l}0.006^{*} \\
(0.001)\end{array}$ & $\begin{array}{c}0.001^{*} \\
(0.0002)\end{array}$ & $\begin{array}{l}1.037^{*} \\
(0.005)\end{array}$ & $\begin{array}{l}0.005^{*} \\
(0.001)\end{array}$ & $\begin{array}{l}0.019^{*} \\
(0.002)\end{array}$ & $\begin{array}{l}0.004^{*} \\
(0.001)\end{array}$ \\
\hline Age & $\begin{array}{c}1.03^{*} \\
(0.003)\end{array}$ & $\begin{array}{l}-0.003^{*} \\
(0.0003)\end{array}$ & $\begin{array}{l}0.014^{*} \\
(0.002)\end{array}$ & $\begin{array}{c}0.003^{*} \\
(0.0003)\end{array}$ & $\begin{array}{l}1.02 * \\
(0.005)\end{array}$ & $\begin{array}{c}-0.006^{*} \\
(0.007)\end{array}$ & $\begin{array}{c}0.006^{* *} \\
(0.003)\end{array}$ & $\begin{array}{c}0.001^{* *} \\
(0.001)\end{array}$ \\
\hline Sex & $\begin{array}{l}0.621^{*} \\
(0.008)\end{array}$ & $\begin{array}{c}-0.049^{*} \\
(0.001)\end{array}$ & $\begin{array}{c}-0.253^{*} \\
(0.007)\end{array}$ & $\begin{array}{c}-0.048^{*} \\
(0.001)\end{array}$ & $\begin{array}{l}0.673^{*} \\
(0.014)\end{array}$ & $\begin{array}{c}-0.048^{*} \\
(0.002)\end{array}$ & $\begin{array}{c}-0.215^{*} \\
(0.011)\end{array}$ & $\begin{array}{c}-0.047^{*} \\
(0.002)\end{array}$ \\
\hline Child & $\begin{array}{l}1.099^{*} \\
(0.007)\end{array}$ & $\begin{array}{l}0.011^{*} \\
(0.001)\end{array}$ & $\begin{array}{l}0.053^{*} \\
(0.003)\end{array}$ & $\begin{array}{c}0.01^{*} \\
(0.001)\end{array}$ & $\begin{array}{l}1.06^{*} \\
(0.01)\end{array}$ & $\begin{array}{l}0.008^{*} \\
(0.001)\end{array}$ & $\begin{array}{l}0.035^{*} \\
(0.006)\end{array}$ & $\begin{array}{l}0.008^{*} \\
(0.001)\end{array}$ \\
\hline Constant & & $\begin{array}{l}0.123^{*} \\
(0.007) \\
\end{array}$ & $\begin{array}{c}-1.76^{*} \\
(0.04) \\
\end{array}$ & & & $\begin{array}{c}0.14^{*} \\
(0.015) \\
\end{array}$ & $\begin{array}{l}-1.74^{*} \\
(0.077) \\
\end{array}$ & \\
\hline
\end{tabular}

Notes:Estimates in bold are marginal effects from the probit model using the first savings proxy. Other Controls: Marital status, year dummies, Age sq. A/A/E American Indian/Aleut/Eskimo

$* 5 \%$ significance

$* * 10 \%$ significance

M.E Marginal Effects 
AAUBP maintain the lowest probability of self-employment relative to the base group, WAUBP. Note that among the African-American subgroups that AAFBP, AAFBF and AAFBM all have higher self-employment probabilities than do AAUBP. More importantly, AAFBP and AAFBF share similar probability of self-employment to that of WAUBP. For Whites, results in Table(4), column (2) seems to suggest little within group differences. WAFBM WAFBF, WAFBPLDC all have similar self-employment probabilities to that of WAUBP. However, WAFBPmix has a higher probability of self-employment probability whereas WAFBPDC seem to have a lower probability of self-employment than do WAUBP. Comparing Blacks and Whites, we find that two subgroups of African-Americans share similar probability of being self-employed in the U.S. to that of U.S. born White Americans. This result could suggest that current racial discrimination is less important in explaining the Black-White self-employment gap. ${ }^{12}$

To further examine the robustness of our results, we re-estimate the model taking a 'kitchen sink' approach. We re-estimate all the probability models including additional factors that could be relevant in the self-employment decision as well as other potential control variables that could impact self-employment probabilities. These factors include cohort of birth, region, whether an individual lives in a metro area, if observation is a male with child, if observation is male and married, family size, if the individual owns a home and the number of children. The results of this analysis are in Table (5), as with all other tables, we focus on marginal estimates. Estimates of the marginal effects using a probit model are in column (2) and (3) whereas estimates using a linear probability model are found in column (1). Results in column (3) combines both wealth indicators and reveals that our results are not dependent on using a particular wealth indicator. However, as noted previously, the sample using both indicators is smaller because of the small number of survey participants that report dividend income. The results with the addition of more control variables confirm the validity of our earlier estimates. Within race differences in self-employment exist among U.S. born African-Americans. AAUBP continue to have a lower self-employment probability (5.5$6.5 \%$ lower probability) than AAFBP. AAFBP and AAFBF continue to share similar probability of self-employment to that of WAUBP. In contrast, AAFBM seem to share a similar probability of self-employment to that of AAUBP. However, when we control for dividend income, the results in column (3) suggest that AAFBM similar to AAFBP, have a higher probability of self-employment than do AAUBP and a similar self-employment probability to that of WAUBP. Given the issues

\footnotetext{
${ }^{12}$ Notice that the results using the second wealth indicator seems to show that AAUBP and AAFBP share similar probability of self-employment. However, this result is not robust and disappears when further controls are included. Also, as mentioned previously, the sample of those with dividend income is small and suffers from a selection bias because individuals select into owning stocks while most adults own a bank account. Given the selectivity issue with this indicator, we are more apprehensive about results with this control and our preferred result uses the interest income indicator.
} 
Table 4: Do within race differences exist in the self-employment gap?

\begin{tabular}{|c|c|c|c|c|}
\hline Variable: & \multicolumn{2}{|c|}{ Panel A: Wealth Proxy A } & \multicolumn{2}{|c|}{ Panel B: Wealth Proxy B } \\
\hline \multicolumn{5}{|l|}{ Dep Var: Dividend Inc. } \\
\hline & \multirow[t]{2}{*}{ Linear } & \multirow{2}{*}{$\begin{array}{c}\text { Probit } \\
\text { Marg.Effect }\end{array}$} & \multirow[t]{2}{*}{ Linear } & \multirow{2}{*}{$\begin{array}{c}\text { Probit } \\
\text { Marg.Effect }\end{array}$} \\
\hline & & & & \\
\hline & $(1)$ & $(2)$ & $(3)$ & $(4)$ \\
\hline log savings & $0.010^{*}$ & $0.009^{*}$ & & \\
\hline & $(0.000)$ & $(0.000)$ & & \\
\hline $\log$ dividend & & & $0.006^{*}$ & $0.006^{*}$ \\
\hline & & & $(0.001)$ & $(0.001)$ \\
\hline AA Foreign Born Mother & $-0.044^{*}$ & $-0.056^{*}$ & $-0.060^{*}$ & $-0.082^{*}$ \\
\hline & $(0.017)$ & $(0.021)$ & $(0.031)$ & $(0.037)$ \\
\hline AA Foreign Born Father & -0.005 & -0.002 & 0.015 & 0.025 \\
\hline & $(0.029)$ & $(0.033)$ & $(0.067)$ & $(0.082)$ \\
\hline AA Foreign Born Parents & -0.017 & -0.020 & $-0.083^{*}$ & $-0.096^{*}$ \\
\hline & $(0.015)$ & $(0.019)$ & $(0.024)$ & $(0.028)$ \\
\hline AA U.S born Parent & $-0.059^{*}$ & $-0.063^{*}$ & $-0.068^{*}$ & $-0.076^{*}$ \\
\hline & $(0.002)$ & $(0.002)$ & $(0.005)$ & $(0.005)$ \\
\hline WA Foreign born parent LDC & -0.008 & -0.008 & 0.007 & 0.003 \\
\hline & $(0.006)$ & $(0.005)$ & $(0.013)$ & $(0.011)$ \\
\hline WA Foreign born parent DC & $-0.014^{*}$ & $-0.012^{*}$ & -0.016 & -0.012 \\
\hline & $(0.005)$ & $(0.004)$ & $(0.010)$ & $(0.009)$ \\
\hline WA Foreign born parent Mix & $0.032^{*}$ & $0.027^{*}$ & $0.056^{*}$ & $0.052^{*}$ \\
\hline & $(0.014)$ & $(0.012)$ & $(0.025)$ & $(0.023)$ \\
\hline WA Foreign born parent Mother & -0.002 & -0.003 & 0.001 & 0.000 \\
\hline & $(0.004)$ & $(0.004)$ & $(0.008)$ & $(0.007)$ \\
\hline WA Foreign born parent father & 0.005 & 0.003 & 0.014 & 0.013 \\
\hline & $(0.004)$ & $(0.004)$ & $(0.008)$ & $(0.007)$ \\
\hline Foreign Black & $-0.042^{*}$ & $-0.047^{*}$ & $-0.056^{*}$ & $-0.074^{*}$ \\
\hline & $(0.008)$ & $(0.009)$ & $(0.019)$ & $(0.021)$ \\
\hline Foreign White from LDC & $-0.009^{*}$ & $-0.009^{*}$ & 0.006 & 0.006 \\
\hline & $(0.004)$ & $(0.004)$ & $(0.013)$ & $(0.014)$ \\
\hline Foreign White DC & $0.036^{*}$ & $0.034^{*}$ & $0.045^{*}$ & $0.045^{*}$ \\
\hline & $(0.008)$ & $(0.008)$ & $(0.015)$ & $(0.015)$ \\
\hline Naturalized White & $0.021 *$ & $0.017^{*}$ & $0.027^{*}$ & $0.025^{*}$ \\
\hline & $(0.004)$ & $(0.004)$ & $(0.009)$ & $(0.008)$ \\
\hline Naturalized Black & $-0.043^{*}$ & $-0.040^{*}$ & -0.036 & -0.035 \\
\hline & $(0.010)$ & $(0.009)$ & $(0.023)$ & $(0.024)$ \\
\hline $\mathrm{A} / \mathrm{A} / \mathrm{E}$ & $-0.017^{*}$ & $-0.017^{*}$ & -0.021 & -0.021 \\
\hline & $(0.008)$ & $(0.008)$ & $(0.015)$ & $(0.016)$ \\
\hline Asian & -0.004 & -0.004 & -0.004 & -0.004 \\
\hline & $(0.003)$ & $(0.003)$ & $(0.006)$ & $(0.006)$ \\
\hline Other & $-0.043^{*}$ & $-0.042^{*}$ & -0.050 & -0.055 \\
\hline & $(0.010)$ & $(0.010)$ & $(0.026)$ & $(0.026)$ \\
\hline
\end{tabular}

Other Controls: marital status, year dummies, age, number of children, age-square, intercept. A/A/E American Indian/Aleut/Eskimo

* $5 \%$ significance $* * 10 \%$ significance 
surrounding the use of dividend income as a wealth proxy, we focus our analysis on results using only the savings proxy.

Considering White U.S born subgroups and focusing on column (2), we note that there is less evidence of within group differences in self-employment. WAUBP, WAFBPDC, WAFBF, WAFBM, WAFBPLDC all have a similar probability of self-employment. Only WAFBPmix have a higher selfemployment probability than do WAUBP. This group has the highest probability of self-employment among the U.S born.

Considering results for African-Americans, Table (5) suggests that the Black-White gap in selfemployment in the U.S is not characteristic of all African-Americans. On average, the probabilities of self-employment in the U.S. for African-Americans whose fathers are foreign born and AfricanAmericans with both parents foreign born are similar to that of WAUBP and are significantly higher than that of African-American with U.S born parents. Comparing all the 18 subgroups, AAUBP have the lowest self-employment probabilities across all subgroups as they have a $5.5 \%$ point lower probability of self-employment than do WAUBP. The addition of more control variables, though useful, only led to a slight reduction in most probabilities. ${ }^{13}$

\section{The Black-White self-employment gap. Do cohort differences exist?}

To test the cohort hypothesis we divide the population into two cohorts. The younger cohort covers those born after 1970 and the older cohort includes all others. We estimate probability models for each cohort and compare the estimate of the Black-White gap. Table (6) summarizes the estimates of the marginal effects. The results are interesting and encouraging. First, we note that the BlackWhite gap with respect to AAUBP exists for both cohorts. However, the gap is significantly smaller for the younger cohort. Younger AAUBP only have a $1.5 \%$ lower probability of self-employment than their WAUBP counterparts. However, this result does not imply that cohort differences exist in self-employment probabilities in general. Specifically, AAFBF,AAFBP, WAFBPLDC WAFPF, WAFPM show no cohort differences in self-employment probabilities. Apart from AAUBP, the results from Table (6) also suggest cohort differences in self-employment probabilities for WAFBPmix,

\footnotetext{
${ }^{13} \mathrm{FB}$ and $\mathrm{NAB}$ are the only other groups with lower probabilities of self-employment than that of the base group at $2.7 \%$ and $2.8 \%$, respectively but are even higher than AAUBP. Though we present the results of immigrant groups also, we do not discuss the results for all non U.S born groups because as highlighted above, it is harder to properly control for wealth for this group who are more likely to save both in the U.S and their home country. Besides given the constraints this group face linked with being immigrants that could affect self-employment and we cannot control for, it would not be useful to compare them with U.S born. For both of these reasons, estimates for immigrant are more likely to be biased.
} 
Table 5: Robustness Checks on Results: Adding on all the controls

\begin{tabular}{|c|c|c|c|}
\hline \multirow[t]{4}{*}{ Variable: } & \multicolumn{2}{|c|}{ Saving Indicator } & \multirow{4}{*}{$\begin{array}{c}\text { Savings and Dividend } \\
\text { Marginal Effects } \\
\text { Probit } \\
\text { (3) }\end{array}$} \\
\hline & Linear & Marginal Effects & \\
\hline & & Probit & \\
\hline & (1) & $(2)$ & \\
\hline \multirow[t]{2}{*}{ log interest income } & $0.010^{*}$ & $0.009^{*}$ & $0.011^{*}$ \\
\hline & $(0.0003)$ & (0.0003) & $(0.001)$ \\
\hline \multirow[t]{2}{*}{$\log$ dividend } & & & $0.004^{*}$ \\
\hline & & & $(0.001)$ \\
\hline \multirow[t]{2}{*}{ AA with U.S. born parent } & $-0.049^{*}$ & $-0.055^{*}$ & $-0.069^{*}$ \\
\hline & $(0.002)$ & $(0.002)$ & $(0.006)$ \\
\hline \multirow[t]{2}{*}{ Foreign Black } & $-0.019^{*}$ & $-0.028^{*}$ & -0.048 \\
\hline & $(0.008)$ & $(0.011)$ & $(0.029)$ \\
\hline \multirow[t]{2}{*}{ AA with foreign born parents } & 0.003 & 0.0003 & -0.082 \\
\hline & $(0.015)$ & $(0.022)$ & $(0.037)$ \\
\hline \multirow[t]{2}{*}{ AA foreign born mother } & $-0.035^{*}$ & $-0.048^{*}$ & -0.061 \\
\hline & $(0.017)$ & $(0.023)$ & $(0.052)$ \\
\hline \multirow[t]{2}{*}{ AA foreign born father } & 0.006 & 0.01 & 0.078 \\
\hline & $(0.029)$ & $(0.035)$ & $(0.103)$ \\
\hline \multirow[t]{2}{*}{ A/Aleut/Eskimo } & $-0.025^{*}$ & $-0.022 *$ & -0.016 \\
\hline & $(0.008)$ & $(0.008)$ & $(0.021)$ \\
\hline \multirow[t]{2}{*}{ Asian/Pacific Islander } & -0.003 & -0.002 & -0.0042 \\
\hline & $(0.003)$ & $(0.003)$ & $(0.007)$ \\
\hline \multirow[t]{2}{*}{ Other } & $-0.039^{*}$ & $-0.036^{*}$ & -0.048 \\
\hline & $(0.01)$ & $(0.01)$ & $(0.030)$ \\
\hline \multirow[t]{2}{*}{ Naturalized White } & $0.029^{*}$ & $0.025 *$ & $0.029 *$ \\
\hline & $(0.005)$ & $(0.004)$ & $(0.008)$ \\
\hline \multirow[t]{2}{*}{ Naturalized Black } & $-0.027^{*}$ & $-0.027 *$ & -0.022 \\
\hline & $(0.01)$ & $(0.01)$ & $(0.028)$ \\
\hline \multirow[t]{2}{*}{ Foreign White LDC } & 0.001 & 0.002 & 0.017 \\
\hline & $(0.004)$ & $(0.005)$ & $(0.017)$ \\
\hline \multirow[t]{2}{*}{ Foreign White from DC } & $0.041^{*}$ & $0.039^{*}$ & $0.046^{*}$ \\
\hline & $(0.008)$ & $(0.008)$ & $(0.016)$ \\
\hline \multirow[t]{2}{*}{ WA foreign born parents LDC } & -0.006 & -0.005 & 0.006 \\
\hline & $(0.006)$ & $(0.005)$ & $(0.012)$ \\
\hline \multirow[t]{2}{*}{ WA foreign born parents DC } & -0.005 & -0.004 & -0.007 \\
\hline & $(0.005)$ & $(0.004)$ & $(0.009)$ \\
\hline \multirow[t]{2}{*}{ WA foreign born parents mix } & $0.040^{*}$ & $0.036^{*}$ & $0.056^{*}$ \\
\hline & $(0.014)$ & $(0.012)$ & $(0.024)$ \\
\hline \multirow[t]{2}{*}{ WA foreign born mother } & -0.001 & -0.002 & 0.002 \\
\hline & $(0.004)$ & $(0.004)$ & $(0.008)$ \\
\hline \multirow[t]{2}{*}{ WA foreign born father } & $0.009^{*}$ & 0.007 & $0.020^{*}$ \\
\hline & $(0.004)$ & $(0.004)$ & $(0.007)$ \\
\hline
\end{tabular}

Note AA- African-American, WA- White American Other Controls: Marital Status, sex, age, year, Age squared, cohort, region, metro area, male with child, male married, head, family size, own home, child. A/A/E American Indian/Aleut/Eskimo, constant.

$* 5 \%$ significance 
WAFBPDC. However, the difference in probabilities are small for these two groups while cohort differences for AAUBP are significant. Specifically, the older cohort has a $6 \%$ lower probability of being self-employed than the younger cohort.

\section{Inferences, Recommendations and Conclusions}

In this paper, we focused on three basic questions. First, is there evidence for a Black-White gap in self-employment between 1994-2002 and could the White immigrant population be driving this result? Second, do significant within race differences exist among the U.S. born in self-employment? Third, do cohort differences in self-employment exist across race among the U.S. born? We find that there is evidence of a Black-White gap in self employment between 1994 and 2002. Our results suggest that this gap is not driven by the White immigrant population who typically have higher probabilities of being self-employed than do any other group. In addition we find that significant within race differences exist among U.S.born Blacks. Our results show that African-Americans with U.S.born parents are the group most responsible for the Black-White gap in self-employment among the U.S. born. U.S.born African-Americans with foreign born parents (AAFBP) have a much higher probability of self-employment than do AAUBP and a similar probability of self-employment to that of U.S.born White with U.S.born parents (WAUBP). Our results also suggest that though the Black-White gap in self-employment is evident in both the younger and older cohorts of the U.S. born, this gap shrinks significantly in younger cohorts. This result may suggest a closing of the self-employment gap over time, which is quite encouraging.

These results raise important questions. Why would some African-Americans have a gap in self-employment and other do not? Second among those who have the gap why would the gap shrink significantly for younger cohorts? These questions are beyond the scope of this paper but Oyelere and Belton (2008) offers an institutional interpretation of these results. They argue that institutional history of African-Americans as it relates to self-employment as well as the information set derived from institutional experiences, interact in building an information stock which provides the foundation for African-American self-employment decisions. African-Americans with U.S. born parents have experienced several shocks that have impeded Black entrepreneurship and led to the failure of Black businesses. Hence, they share a unique information set unlike any other U.S. ethnic/racial group. When societal groups experience many negative shocks from institutional failures that seem to lead to more difficult entry into self-employment and/or a higher probability of failure upon entry, then over time this information becomes embedded in the information stock that is transmitted from one generation to the next. Even when the actual institutions that lead 
Table 6: Evidence of Cohort Differences in Self employment across groups

\begin{tabular}{|c|c|c|c|}
\hline Group & $\begin{array}{l}\text { Sample } \\
\text { Size }\end{array}$ & $\begin{array}{c}\text { Marginal Effects } \\
\text { Post } 1970 \\
\text { Cohort }\end{array}$ & $\begin{array}{c}\text { Marginal Effects } \\
1900-1970 \\
\text { Cohort }\end{array}$ \\
\hline & $(1)$ & $(2)$ & $(3)$ \\
\hline AA with U.S. born parent & 119,958 & $\begin{array}{c}-0.015^{*} \\
(0.003)\end{array}$ & $\begin{array}{l}-0.075^{*} \\
(0.002)\end{array}$ \\
\hline Foreign Black & 6,163 & $\begin{array}{c}-0.024^{*} \\
(0.005)\end{array}$ & $\begin{array}{l}-0.052^{*} \\
(0.011)\end{array}$ \\
\hline AA with foreign born parents & 4,692 & $\begin{array}{l}-0.02 \\
(0.008)\end{array}$ & $\begin{array}{l}-0.011 \\
(0.002)\end{array}$ \\
\hline A/Aleut/Eskimo & 18,368 & $\begin{array}{c}-0.001^{*} \\
(0.011)\end{array}$ & $\begin{array}{c}-0.021^{*} \\
(0.01)\end{array}$ \\
\hline Asian/Pacific Islander & 47,487 & $\begin{array}{l}-0.001 \\
(0.004)\end{array}$ & $\begin{array}{l}-0.005 \\
(0.004)\end{array}$ \\
\hline Other & 5,579 & $\begin{array}{l}-0.013 \\
(0.02)\end{array}$ & $\begin{array}{c}-0.050^{*} \\
(0.011)\end{array}$ \\
\hline Naturalized White & 31,427 & $\begin{array}{c}0.012 \\
(0.011)\end{array}$ & $\begin{array}{l}0.018^{*} \\
(0.004)\end{array}$ \\
\hline Naturalized Black & 3,374 & $\begin{array}{c}0.03 \\
(0.038)\end{array}$ & $\begin{array}{c}-0.051^{*} \\
(0.011)\end{array}$ \\
\hline Foreign White LDC & 61,327 & $\begin{array}{l}-0.004 \\
(0.005)\end{array}$ & $\begin{array}{l}-0.012^{*} \\
(0.005)\end{array}$ \\
\hline Foreign White from DC & 7,059 & $\begin{array}{l}0.008^{*} \\
(0.011)\end{array}$ & $\begin{array}{l}0.037^{*} \\
(0.009)\end{array}$ \\
\hline WA foreign born parents LDC & 46,993 & $\begin{array}{l}-0.001 \\
(0.006)\end{array}$ & $\begin{array}{l}-0.012 \\
(0.006)\end{array}$ \\
\hline WA foreign born parents DC & 28,044 & $\begin{array}{c}0.004 \\
(0.008)\end{array}$ & $\begin{array}{l}-0.016^{*} \\
(0.005)\end{array}$ \\
\hline WA foreign born parents mix & 4,630 & $\begin{array}{c}0.007 \\
(0.023)\end{array}$ & $\begin{array}{l}0.029^{*} \\
(0.014)\end{array}$ \\
\hline WA foreign born mother & 28,469 & $\begin{array}{c}0.009 \\
(0.005)\end{array}$ & $\begin{array}{l}-0.002 \\
(0.005)\end{array}$ \\
\hline WA foreign born father & 35,264 & $\begin{array}{l}-0.001 \\
(0.006)\end{array}$ & $\begin{array}{c}0.004 \\
(0.004)\end{array}$ \\
\hline AA foreign born father & 1,517 & $\begin{array}{c}0.05 \\
(0.055)\end{array}$ & $\begin{array}{l}-0.022 \\
(0.036)\end{array}$ \\
\hline AA foreign born mother & 1,450 & $(0.0)$ & $\begin{array}{l}-0.057 \\
(0.028)\end{array}$ \\
\hline
\end{tabular}

Note AA- African-American, WA- White-American Other Controls: saving proxy, marital status, sex, age, year, Age squared, cohort, region, metro area, male with child, male married, head, family size, own home, child. A/A/E American Indian/Aleut/Eskimo, constant.

$* 5 \%$ significance 
to self-employment failure and low success probabilities have disappeared, the stock of information remains and tends to impact perception, expectation of success, and self-employment entry decisions over the long-run.

The results found in this paper provide new information on within race differences and cohort differences in African-American's self-employment. It is our hope that these results will create a dialogue among economists about possible explanations for these results.

\section{References}

[1] Bease, P.J. (1984). "An Econometric Analysis of Black Entrepreneurship," The Journal of Black Political Economy, pp. 111-134

[2] Belton, Willie \& Uwaifo Oyelere, Ruth, 2008. "The Racial Saving Gap Enigma: Unraveling the Role of Institutions," IZA Discussion Papers 3545, Institute for the Study of Labor (IZA).

[3] Bates, Timothy. (1997). Race, Self-Employment \& Upward Mobility: An Illusive American Dream, Washington, D.C.: Woodrow Wilson Center Press and Baltimore: John Hopkins University Press.

[4] Bates, Timothy, (Sept.1987) "Self-Employed Minorities: Traits and Trends," Social Sciences Quarterly 68, 539-550.

[5] Borjas, George J \& Bronars, Stephen G, 1989. "Consumer Discrimination and Selfemployment," Journal of Political Economy, University of Chicago Press, vol. 97(3), pages 581-605, June.

[6] Blanchflower David G. and Andrew J. Oswald. 1998. "What Makes an Entrepreneur?" Journal of Labor Economics, 1998, 16, 26-60.

[7] Blanchflower, David G. \& Phillip B. Levine \& David J. Zimmerman, 2003. "Discrimination in the Small-Business Credit Market," The Review of Economics and Statistics.

[8] Blau, Francine D \& Graham, John W, 1990. "Black-White Differences in Wealth and Asset Composition," The Quarterly Journal of Economics, MIT Press, vol. 105(2), pages 321-39, May

[9] Bogan, Vicki and William Darity, Jr. Culture and Entrepreneurship? African-American and Immigrant Self-Employment in the United States. Journal of Socio-Economics. 37 (5), 19992019. October 2008. 
[10] Evans, David S. and Linda S. Leighton. 1989. "Why Do Smaller Firms Pay Less?" Journal of Human Resources 24(2):299-318.

[11] Fairlie, Robert W. 1999. "The Absence of the African-American Owned Business: An Analysis of the Dynamics of Self-Employment." Journal of Labor Economics, 17(1): 80- 108.

[12] Fairlie, Robert W., and Bruce D. Meyer. 1996. "Ethnic and Racial Self-Employment Differences and Possible Explanations." Journal of Human Resources 31(4):757-793.

[13] Fairlie, R. W., \& Meyer, B. D. 2000. "Trends in Self-Employment Among White and Black Men During the Twentieth Century." The Journal of Human Resources, 35 (4), p. 643-669.

[14] Fairlie, Robert W. and Alicia M. Robb 2007 "Why Are Black-Owned Businesses Less Successful than White-Owned Businesses? The Role of Families, Inheritances, and Business Human Capital". Journal of Labor Economics, 2007, vol. 25, issue 2, pages 289-324.

[15] Lentz, B. and Laband, D., "Entrepreneurial Success and Occupational Inheritance Among Proprietors," Canadian Journal of Economics, 23,(3), pp.563-579, 1990.

[16] Lofstrom, M.J. and Bates, T. 2007. African-Americans' Pursuit of Self-Employment (with Timothy Bates), IZA DP No.

[17] Uwaifo Oyelere. R and Belton, W. 2008, The Role of Information and Institutions in Understanding the Black-White Gap in Self-Employment. IZA Discussion Papers 3761, Institute for the Study of Labor (IZA).

[18] Uwaifo Oyelere, Ruth and Belton, Willie J., 2009. Coming to America: Does Immigrant's Home Country Economic Status Impact the Probability of Self-Employment in the U.S..? IZA Discussion Paper No. 4178. Available at SSRN: http://ssrn.com/abstract=1409282 